\title{
Micro Financing as Strategy for Poverty Alleviation and Economic Empowerment in Osun State, Nigeria
}

\author{
JONES Olasimbo Clement \\ Department of Business and Entrepreneurship, School of Business and Governance, Kwara State University, \\ Malete, Nigeria
}

\begin{abstract}
The focus of this study is to examine the Impact the micro loans being granted by Nigerian Financial Institutions have on the poverty level and the empowerment of the people of Osun State of Nigeria as evidenced from selected Financial Institutions in Osun State. The methodology adopted was descriptive survey research method; this method of research was used in order to analyze microcredit and loans from financial institutions that serve as catalyst for economic growth and reduction in poverty level in the State. The population of the study is financial institutions in Osun State; 5 commercial and 5 micro finance banks were selected, using simple random sampling procedure. 10 staff was administered questionnaire in each bank, making 100. However, 85 questionnaires were properly returned and accounted for, while 15 were unreachable. Simple regression analysis was used to test hypothesis in order to determine the degree of connections between the variables with the aid of Statistical Package for Social Science (SPSS) version 23. Findings show that availability of microcredit is statistically significant in predicting the dependent variable (reducing poverty).
\end{abstract}

Keywords: Strategy, Financial Institutions, Commercial Banks, Microfinance Banks, Microcredit, Poverty Reduction. Economic Empowerment.

DOI: $10.7176 / \mathrm{EJBM} / 11-5-06$

\section{Introduction}

In Nigeria, as around the World, most micro-financing can be grouped in three areas: financial services (loans, deposits, leasing, etc.), non-financial services (classes on literacy, numeracy, health, nutrition, etc.) and business development. However, it is a good indication of whether the company is even capable of generating a return that is worth whatever risk the investment may entail (Berman, Knight and Case, 2013). Thus, while the debate still rages on about the effect of development of banking industry on poverty, it is established that when microfinance institutions recognize the needs of the poor and meet those needs, microfinance schemes can have positive impacts on alleviating the susceptibility, not just for the poor, but also for the poorest in the society. In Nigerian banking industry, the importance of microcredit to the growth of any economy can never be overemphasized, as it is the solution to helping the poor. Micro-enterprises or small businesses are important in situations where economic and social environments have had a disappointing effect on the people, so that the poor can survive under microfinancing. Yet these small businesses play a great role in providing jobs thereby contributing positively to the GNP - Gross National Product. Despite this, the enabling environment is still lacking in Africa to make this function well.

The Nigerian economy is full of attempts at alleviating poverty especially among vulnerable groups based on cooperative ideals with large degrees of failure. The view of many authors is that micro credit through cooperative does not automatically guarantee poverty alleviation. They maintained that for success to be achieved, such empowerment schemes should be supported with training and mentoring and not largely on loan administration, efficient cooperative management, and on whether the organized cooperative is routed on felt needs of the citizenry rather than on undue emphasis on business orientation and profitability. Being an individual beneficiary of microfinance loan is regarded as a derived one from the household perspective. In essence, if one or more members of a household obtain microfinance loan, the entire household is classified as beneficiary (Ashraf \& Ibrahim, 2014). Microfinance has become an increasingly popular tool for poverty alleviation in developing countries for the past two decades, this is not surprising because it is a well-known fact that micro-finance holds enormous potential for national economic growth and development by supporting the economic activities of the poor who are essentially the majority.

\section{Statement of the Problem}

Since 1987, the Nigerian efficacy of microcredit through the financial institutions and cooperative regime to alleviate poverty has come under a paucity of loanable funds, absence of support institutions in the sector, unwillingness of conventional banks to support micro enterprises, weak internal control, poor credit administration and asset quality, low management capacity and unavailability of clients. Microfinance schemes have not been used as a means for poor households to gain access to much needed credit services that are appropriate for their needs and to reduce unemployment in Nigeria. To be poor connotes deprivation from the basic necessities of life. In fact, poverty engenders inability to afford the minimum basic essentials like food, children education, good 
housing, healthcare and good clothing to mention few (Todaro\& Smith, 2011).

The specific statements of problem are highlighted below: -

1. Most financial institutions in Nigeria have not been able to provide micro credit to the unemployed youth in order to reduce poverty. Factors affecting performance of financial institutions according to profitability are broadly categorized into two; internal or micro and external or macro factors (Sehrish et.al 2011).

2. Unavailability of empowerment scheme to reduce poverty in the country is another challenge that the banking industry is facing in Nigeria. In other words, the poor lacks basic infrastructure such as education, health, potable water, and sanitation, and as a result has limited chance of advancing his/her welfare to the limit of his/her limited access to social and economic infrastructures, therefore the poor lacks capabilities.

3. Unimplemented economic development strategy that aims at poverty reduction by providing skill acquisition services to the poor, low income earners households and micro-entrepreneurs that are deprived of getting the same services from the formal financial market.

4. Neglect of the informal market which are the market women, shoe cobblers, road side food sellers and motor mechanics and so on. Most financial institutions have not included these into their programme.

\section{Objectives of the Study}

The aim of this study is to examine the impact of Financial Institutions' micro loans on poverty reduction and economic empowerment in Nigeria: Evidence from selected Financial Institutions in Osun State.

The specific objectives of this study are to: -

1. Examine if financial institutions in Osun State can provide micro credit to the unemployed populace in order to reduce poverty and create economic empowerment.

2. Determine if empowerment scheme can reduce poverty in the country.

\section{Hypotheses of the study}

$\mathrm{H}_{01}$ There is no significant relationship between micro credit provided by the financial institutions and level of poverty among the unemployed populace.

$\mathrm{H}_{02}$ There is no significant relationship between empowerment scheme and level of poverty reduction in the country.

\section{Literature Review}

According to Central Bank of Nigeria (2015), microfinance is about providing financial service to the poor who are traditionally not served by conventional financial institutions. It is also defined microfinance as the provision of thrift, credit and other financial services and products in very small amounts to the poor to enable them to raise their income levels and improve their standard of living.

Microfinance is a term used to refer to the activity of provision of financial services to clients who are excluded from the traditional financial system on the account of their lower economic status (Odetayo, 2016).

As previous studies show, microfinance does make great contributions in improving the economic situation of people and increase their empowerment (Awojobi, 2014). However, there are some factors that limit the effectiveness of Micro finance (Odetayo, 2016). For example, lack of finance needed to expand financial services to clients, diverting microfinance fund to friends and relatives, poor lending and questionable governance and management arrangement, unfavorable and frequent changes in government policies, high risk, heavy transaction cost and mounting loan losses, and low capacity and low technical skills on micro financing as major challenges of MFIs in Nigeria.

Microfinance evolved as an economic development approach intended to benefit the low-income part of a given society, both men and women (Irobi, 2008). According to World Bank (2007), the term refers to provision of financial services (including saving and credit) to the poor. Micro-finance banks therefore are institutions that are established to provide financial services to the poor. Microfinance Institutions can be non-governmental organizations, savings and loan cooperatives, loan unions, government banks, commercial banks or non-bank financial institutions (Irobi, 2008).

Earlier studies about micro-financing have evaluated whether micro-credit programs such as popular in Nigeria reach the relatively poor and vulnerable in their operations. Recent studies have shown evidence of positive impact as it relates to first six out of seven Millennium Goals (Irobi, 2008).

\subsection{Empowerment Scheme of Banking Industry}

The Government of Nigeria on its own has made several efforts at readdressing the inadequate supply of financial services to the poor. In 1936, government in support of the cooperatives promulgated the cooperative society's ordinance. This made the cooperatives have regular/compulsory savings as one of their goals while thrift and credit 
societies combined regular savings of members with lending. It is also disheartening that one child out of five living in these poor communities does not live to see his or her fifth birthday! No wonder that the United Nations declared Millennium Development Goals (MDGs) in September 2000 to ensure global development. Ironically, in Sub-Saharan Africa which is considered as the World's poorest region, the concept of poverty is relatively understudied and has attracted less attention in academic literature (Ssewamala, Sperber, Zimmerman, \&Karimli, 2010). To this effect, little efforts have been made to critically analyse the impact of microfinance programmes on poverty alleviation, particularly in Sub-Saharan Africa. This paper examined the contributions of Nigerian banking industry towards poverty reduction. To this end, the Nigerian government established several programmes to alleviate poverty. In 1972, the National Accelerated Food Production Programme was inaugurated to boost the food production through an on lending fund from the Nigeria Agricultural and Cooperative Bank. In 1976, Operation Feed the Nation was established to provide extension services to farmers in the rural areas. While The Green revolution programme of 1979 was to put an end to food importation and encourage the production of more crops and fiber. Others are: The Directorate of Food Road and Rural Infrastructure (DFRRI) in 1986, The Community Banks of Nigeria, The Peoples Bank, The Family Economic Advancement Programme (FEAP), The Mass Mobilization for Self-Reliance (MAMSER), the Better Life Programme (BLP), The Family Support Programme (FSP) in 1993, The National Directorate of Employment (NDE), The Petroleum Special Trust Fund (PTF), The Mass Transit Programme (MTP), The Agency for Mass Literacy, National Economic Empowerment and Development Strategy (NEEDS); and the Microfinance Banks. Also, Interest rates determine the cost of borrowing and can therefore have a significant impact on equity returns (Nielsen, 2011).

The Commercial Bill Financing Scheme in 1962 and the Regional commodity Boards (later called National Commodity Boards in 1977) were among the efforts made by government to improve the poor's access to lending. The Nigerian Agricultural and Cooperative Bank (NACB) was established in 1972 to act as development finance institution extending loans to both small and large-scale farmers. A similar institution, the Agricultural Credit Guarantee Scheme Fund (ACGSF) was established in 1978 for the purpose of agricultural risk reduction. The bank guarantees up to $75 \%$ of the principle in case of default due to natural events beyond the control of the farmers. Others are the Rural Banking System of 1977, where banks were required to establish a specified number of branches in identified rural areas. Export Financing Rediscount Facility in 1987, measured rural credit markets, including the sectorial allocation of credit, specified percentage of total deposits mobilized in the rural areas to be lent to borrowers in such areas, concessional interest and grace periods on agricultural loans. When those that had financial services from the informal sector such as savings clubs/pools, and money lenders were included, the total access percentage for 2010 was 53.7 percent which means that 46.3 percent or 39.2 million adult population were financially excluded in Nigeria $(\mathrm{CBN}, 2012)$.However, some of these measures were abolished with the introduction of liberal economic policies in 1989. The Peoples Bank established in 1989 for the same purpose, was charged with the responsibility of taking deposits and lending to the poor. There was also licensing of community banks in the 1990s for the provision of non-sophisticated loans to the community. One of the most important roles of access to credit is that it enables the poor who normally do not have one source of income or livelihood, but resort to a mixture of activities depending on the season, prices, their health and other contingencies to acquire capital for the financing of multiple petty projects.

Income in Nigeria is closely linked to social and economic status: whilst the upper and middle classes inhabit the 'formal income from their formal ventures and employment, on the other hand, the poorest and low income status are largely 'informally' employed. As at December, 2010, a total of 866 microfinance banks and 3 credit bureau have been established. Similarly, the microfinance certification programme for operators of microfinance banks has been put in place, while the regulatory and promotional machinery have been beefed up (The Nigerian Microfinance Newsletter, 2010). Low income households are not usually involved in regular income occupations and therefore wait for job creation strategies to absorb them; they permanently inhabit' a dependent segment of the so called developing Nigerian economy, in which opportunities for jobs, or for independent and self-sustaining entrepreneurial capital accumulation, are minimal. Though poverty reduction has long been a high priority for the Government of Nigeria, microfinance is still an experimental tool in its overall strategies. The Federal Government of Nigeria has over the year's demonstrated strong commitment to the provision of financial services and economic empowerment of the poor and low income groups. The critical role of finance in the realization of the goals motivated the government, in collaboration with the Central Bank of Nigeria, to formulate the Financial System Strategy (FSS) 2020 in 2007, as part of an overall National vision, which aims to make Nigeria one of the 20 largest economies in the world by 2020 .

\section{Methodology}

This research study adopted survey research method to examine empowerment scheme and poverty alleviation by microfinance and commercial banks in Osun State, Nigeria. Descriptive survey research design was adopted for this study; structured questionnaire was designed to obtain data from respondents on poverty alleviation, reduction of unemployment rate through microcredit and empowerment scheme. The reason for the use of survey research 
method is that it enhances research data analysis and commonly used in similar research of this nature and it is of better adoption in Nigeria. The population of the study is financial institutions in Osun State, 5 commercial and 5 micro finance banks were selected, using simple random sampling procedure. 10 staff was administered questionnaire in each banks, making 100. However, 85 questionnaires were properly returned and accounted for, while 15 were unreachable. The reliability test was piloted to ascertain whether the instrument was reliable. The result of the pilot study indicates a high level of instrument consistency: financial institutions' micro loans $($ Cronbach Alpha $=0.85)$ and reducing poverty (Cronbach Alpha $=0.82)$. Simple regression was used to test hypothesis to determine the degree of connections between the variables with the aid of Statistical Package for Social Science SPSS version 23.

\section{Results, Interpretation and Discussion of findings}

There is significant relationship between micro loans and poverty reduction.

Model Summary

\begin{tabular}{|l|l|l|l|l|}
\hline Model & R & R Square & Adjusted R Square & Std. Error of the Estimate \\
\hline 1 & .193 & .0387 & .014 & 1.18570 \\
\hline
\end{tabular}

Predictors: (Constant), financial institutions' micro loans

Dependent Variable: Poverty reduction

\begin{tabular}{|c|c|c|c|c|c|}
\hline \multicolumn{6}{|c|}{ ANOVA } \\
\hline Model & Sum of Square & Df & $\begin{array}{l}\text { Mean } \\
\text { Square }\end{array}$ & $\mathrm{F}$ & Sig. \\
\hline $\begin{array}{l}\text { Regression } \\
1 \quad \text { Residual } \\
\text { Total }\end{array}$ & $\begin{array}{l}2.093 \\
45.343 \\
58.690\end{array}$ & $\begin{array}{l}1 \\
37 \\
37\end{array}$ & $\begin{array}{l}2.066 \\
1.507\end{array}$ & 32.677 & $.000^{\mathrm{b}}$ \\
\hline
\end{tabular}

a. Dependent Variable: reducing Poverty

Coefficients $^{\mathrm{a}}$

\begin{tabular}{|c|c|c|c|c|c|}
\hline \multirow[b]{2}{*}{ Model } & \multicolumn{2}{|c|}{$\begin{array}{l}\text { Unstandardized } \\
\text { Coefficients }\end{array}$} & \multirow{2}{*}{$\begin{array}{l}\text { Standardized Coefficients } \\
\text { Beta }\end{array}$} & & \multirow[t]{2}{*}{ Sig. } \\
\hline & $\mathrm{B}$ & Std.Error & & & \\
\hline $\begin{array}{l}\text { (Constant) } \\
\text { 1. Financial institutions }\end{array}$ & $\begin{array}{l}3.128 \\
.168\end{array}$ & $\begin{array}{l}.524 \\
.151\end{array}$ & .178 & $\begin{array}{l}3.962 \\
1.235\end{array}$ & $\begin{array}{l}.000 \\
.000\end{array}$ \\
\hline
\end{tabular}

a. Dependent Variable: reducing Poverty

\subsection{Interpretation}

The output of the simple regression outcome as seen above shows that Financial Institutions' micro credit is statistically significant in predicting the dependent variable (reducing poverty). In a nutshell, given all the associated significant $p$-value to be less than $0.05>0.000$ for the dependent variable. The coefficient of determination $\left(\mathrm{R}^{2}=0.387\right)$ indicates that the predictor variable (reducing poverty) is responsible for $39 \%$ variation on the dependent variable. Consequently, the $61 \%$ remaining variations might be due to other factors not considered in this study. We can basically determine that Financial Institutions 'micro loans had a significant impact on poverty alleviation in Nigeria. Likewise, the test of the overall model was found to be statistically significant, given $\mathrm{F}$-value of 32.677 and $\mathrm{p}=0.000$.

\subsection{Findings/Discussion}

This empirical study was directed in determination of the effect of financial institutions 'micro loans on reduction of poverty in Osun State, Nigeria. Statistical test was applied to test hypothesis. Therefore, the statistical results at a significant level of 0.05 became clear that financial institutions 'micro loans has significant impact on poverty reduction in Nigeria. The discovery of this study is in line with the submissions of who affirm that poverty reduction and standard living can be improved with microcredit, empowerment scheme and skill acquisition. It is worthy to note that economic development strategy should be seen as a vital component of Nigerian banking industry.

\section{Conclusion}

Poverty has been identified as a debilitating cankerworm among human society; its effects are felt more in the developing countries. The World Bank Report (2014) listed Nigeria third in the league of five countries with the largest number of the poor. Unemployment and inaccessibility of credit are among the factors that exacerbate poverty. Micro financing has been globally identified by development practitioners as an escape route from poverty. The Central Bank of Nigeria, in imbibing the microfinance catechism establish the microfinance framework in 2005 by which the existing community banks transformed into microfinance banks (CBN 2005). This study 
therefore set out to examine the impact of financial institutions 'micro loans as a means of reducing poverty: evidence from selected financial institutions in Osun State. The study shows that availability of micro credits and loans to unemployed youth and populace; coupled with empowerment programs will definitely lead to employment generation which will in turn reduce poverty in Nigeria.

\section{Recommendations}

Core microfinance banks should be encouraged; presently the country has more of micro-deposit money banks masquerading as microfinance banks. The central bank through its restrictive monetary policy has left a number of commercial banks unable to grant loans that are enough to meet up with the required reduction of poverty and unemployment rate in Nigeria. Commercial banks, Microfinance banks and Development banks should inculcate economic development programs that will enrich the general public financially. Microcredit should be given without long tedious process, high interest rate and collateral, this will not scare customers away from getting financial grants. The Nigerian banks should be less aggressive in their pursuit for profit, the promoters of the banking industry should be less capitalist and more socialists. They should also increase their expenditure on organizing seminars on training and empowerment schemes of graduates in the communities. Giving out loans should be gender sensitive, women, especially the rural women should be encouraged to embrace microfinance banking as a route to escape from poverty. The government, non-governmental organizations (NGOs), community based organizations (CBOs) and faith based organizations (FBOs) should set up microfinance banks. With this strategy in place, in the banking sector, if properly implemented, it will go a long way in reducing unemployment and poverty in Osun State and in the country at large.

\section{References:}

Central Bank of Nigeria (2005). Regulatory and Supervisory Framework for Microfinance Banks in Nigeria.

Ashraf, M. A., \& Ibrahim, Y. B. (2014). Poverty Alleviation and Identifying the Barriers to the Rural Poor Participation in MFIs: A Case Study in Bangladesh. Journal of Economic Cooperation and Development,35(3), 99-132.

Berman, K., Knight, J., Case, J. (2013). Financial Intelligence. A Manager's Guide to Knowing What the Numbers Really Mean. Business Literacy Institute, Inc. USA.

Todaro, P. T., \& Smith, S. C. (2011). Economic Development. England: Pearson. Yang,

B., Jialali, P., \& Wei, X. (2011). Microfinance in China's Poor Area and Its Impact to Loan Type -Evidence from Xinjiang Uygur Autonomous Region. 2011 Fourth International Conference on BusinessIntelligence and Financial Engineering, 486-490. http://dx.doi.org/10.1109/BIFE.2011.82

Sehrish G.; FaizaIrshad\& Khalid Zaman (2011). Factors Affecting bank Profitability in Pakistan. The Romanian Economic Journal Year XIV, No.30 March 2011

Franke, S. (2013): Bonn, Germanu: DVV International. Retrieved on 9th June, 2014 from http://www.dvvinternational. de/files/ipe_68_gb_web.pdf.

Adebayo, A. A. (2009). "Theoretical Perspectives on Poverty Reduction: Challenges for Policy inNigeria", International Journal of Economics and Development Issues, 8(1\&2): 34-43.

Lindvert, M. (2006). "Sustainable Development Work and Micro Finance: A Case Study of howECLOF Ghana is Working Towards Financial Sustainability". Thesis submitted to the Departmentof Social Sciences, Mid Sweden University.

Kurmanalieva, E., Montgomery, H. and Weiss, J. (2003). "Microfinance and Poverty Reduction in. Asia: What is the Evidence?". A paper presented for the 2003 Asian Development BankInstitute Annual Conference on Microfinance and Poverty Reduction, Tokyo December 5th 2003.

Haley, B. (2001). "Analysis of the Effects of Microfinance on Poverty Reduction". NYU Wagner Working Paper No. 1014. Retrieved on 2/9/2010 from http://www.nyu.edu/wagner/workingpapers.html

Momoh, J. (2005). "The Role of Microfinance in Rural Poverty Reduction in DevelopingCountries". Retrieved on 2/9/2010 from http://www.wi.hswismar. de/diewismarerdiscussionpaper

McGee, R. (2002). Knowing Poverty: Critical Reflections on Participatory Research and Policy. London: Earthscan Publication.

Murduch, J. and Hashem, S. (2003). "Is Microfinance an Effective Strategy to reach the Millennium Development Goals", retrieved on 2/9/2010 from jds.sagepub.com/content/25/1/85.ref

Berman, K., Knight, J., Case, J. (2013). Financial Intelligence. A Manager's Guide to Knowing What the Numbers Really Mean. Business Literacy Institute, Inc. USA.

Ashraf, M. A., \& Ibrahim, Y. B. (2014). Poverty Alleviation and Identifying the Barriers to the Rural Poor Participation in MFIs: A Case Study in Bangladesh. Journal of Economic Cooperation and Development,35(3), 99-132.

Almajali, Y. A., Alamro, S. H., \& Al-Soub, Y. Z. (2012). Factors Affecting the Financial Performance of Jordanian Insurance Companies Listed at Amman Stock Exchange. Journal of Management Research, Vol.4 No.15 
Almazari, A. A., (2014). Impact of Internal Factors on Bank Profitability: Case Study of East Africa. Journal of Applied Finance and Banking, Vol.4 No.17

Owoputi (2014). "Microfinance, Poverty Alleviation and Empowerment of Women: AStudy of two NGOs from Andhra and Pradesh". Retrieved on 2/9/2010 from www.istr.org/abstracts2010/pdf/str2010_0274.pdf

Nielsen. (2007). Introduction to Research Methodology, Onitsha: Africana-First PublishersLtd.Central Bank of Nigeria. (2005). Nigeria Poverty Profile 2010. Retrieved fromhttp://reliefweb.int/report/nigeria/nigeriapoverty-profile-2010-report

Price (2012). "Policies and Programmes for Poverty Reduction in RuralNigeria". Interim Research Report Submitted to the African Economic Research Consortium(AERC) Nairobi for the Second Phase Collaborative Poverty Research Project.

Akinrinade, G.O. (2010): The Economic Crises, A Challenge to Nigerian Women. A Journal of Nigeria Association of Teachers of Technology (NATT), Vol. 1 No. 2.

Asomuga, (2009): Global Meltdown and the Lengthening Unemployment Queue. New Nigeria Newspaper, $23^{\text {rd }}$ April.

El-Komi, M. S. (2010). Poverty Alleviation through Microfinance and Implications on Education. Dissertation Publishing UMI13421471, ProQuest.

Kalirajan, K., \& Singh, K. (2009). The Pace of Poverty Reduction Across the Globe: An Exploratory Analysis.

Yahaya, K. A., Osemene, O. F., and Abdulraheem. A., (2011). Effectiveness of Microfinance Banks in Alleviating Poverty in Kwara State Nigeria. Global Journal of Management and Business Research Volume 11 Issue 4 Version 1.0, Publisher: Global Journals Inc. (USA), ISSN: 0975-5853.

Kurfi, I. M. (2009). "The Socio-Economic Effects of Poverty on Nigerian Development". International Journal of Economic and Development Issues, 8(1 \& 2): 173-184.

Brock, T. and McGee, R. (2002). Knowing Poverty: Critical Reflections on Participatory Researchand Policy. London: Earthscan Publication.

Khandker, S.R. (2003). "Microfinance and Poverty: Evidence Using Panel Data fromBangladesh". Retrieved on2/9/2010 from http://econ.worldbank.org

Muller, C., \&Bibi, S. (2010). Refining Targeting against Poverty. Evidence from Tunisia. Oxford Bulletin of Economics and Statistics, 72(3), 381-410. http://dx.doi.org/10.1111/j.1468-0084.2010.00583.x

Asghar, N. (2012). Micro Financing for Poverty Reduction: An Empirical Study of Rural Areas of Tehsil GujratPakistan. International Journal of Advances in Management and Economics, 1(4), 14-19. Retrieved from http://www.managementjournal.info.

Irobi, N.C. (2008), Microfinance and Poverty Alleviation: A case study of Oba Progressive Women Association Mbieri Imo State- Nigeria. Uppsala: Department of Economics. 